\title{
The fourth major restriction factor against HIV/SIV
}

\author{
Masako Nomaguchi ${ }^{1}$, Mikako Fujita ${ }^{2}$ and Akio Adachi ${ }^{1}{ }^{*}$ \\ 1 Department of Microbiology, Institute of Health Biosciences, The University of Tokushima Graduate School, Tokushima, Japan \\ 2 Research Institute for Drug Discovery, School of Pharmacy, Kumamoto University, Kumamoto, Japan \\ ${ }^{*}$ Correspondence: adachi@basic.med.tokushima-u.ac.jp
}

Human and simian immunodeficiency viruses (HIV/SIVs) carry a unique set of accessory proteins that enhance virus replication in an optimized manner. These viral proteins specific to HIV/SIVs are designated Vif, Vpx, Vpr, Vpu, and Nef, and are functional in certain cell types (Malim and Emerman, 2008; Fujita et al., 2010). While viruses of the HIV-1 group do not encode Vpx, the other HIV-2/SIVs are unable to replicate in cells of the myeloid lineage such as monocyte-derived dendritic cells (MDDCs) and macrophages (MDMs) in the absence of Vpx (Fujita et al., 2010). Vpx and its structural close relative $\mathrm{Vpr}$ are least well studied and understood with respect to their functional details (Khamsri et al., 2006; Fujita et al., 2010). Vpx had been long thought to be critical for the nuclear import of viral DNA in non-dividing cells until we and others have independently and clearly demonstrated that it is essential for the reverse transcription of viral RNA in MDDCs (Goujon et al., 2007) and MDMs (Fujita et al., 2008; Srivastava et al., 2008). Subsequently, these results have been well confirmed by the other studies (Goujon et al., 2008; Gramberg et al., 2010). We have also shown that the deletion of $\mathrm{Vpr}$ has only a modest (HIV-1) or almost no (HIV2) effects on viral replication in MDMs (Fujita et al., 2010). On the basis of the new findings about HIV/SIV Vpx by us and others described above, it has been established that there is an innate factor against viral reverse transcription in cells of the myeloid lineage, and that Vpx counteract the factor responsible for the inhibition (Sharova et al., 2008; Bergamaschi et al., 2009; Kaushik et al., 2009). Of a particular note, the Vpxmediated enhancement of viral replication is also applicable to HIV-1 infection (Goujon et al., 2008). Taken all together, it had been well predicted that an unidentified factor present in the myeloid cells is potently effective against a wide variety of retroviruses. Many active HIV/SIV researchers, therefore, had focused on its identification to better understand the life cycle of primate immunodeficiency viruses. Finally, Laguette et al. (2011) have identified SAMHD1 as the myeloid antiviral factor. If confirmed scientifically, SAMHD1 would represent the fourth (and most probably the last) major restriction factor against HIV/SIV (Table 1). SAMHD1 was initially identified in human dendritic cell cDNA library as an ortholog of a mouse interferon- $\gamma$-induced protein that is up-regulated in response to viral infections (Li et al., 2000; Prehaud et al., 2005; Hartman et al., 2007; Zhao et al., 2008). Mutations in the gene encoding SAMHD1 have been shown to be responsible for $5 \%$ of genetically inherited Aicardi-Goutières syndrome cases characterized by inappropriate activation of immune system and aberrant interferon- $\alpha$ secretion (Rice et al., 2009). This syndrome is a mimic of congenital infection and also shows an overlap with systemic lupus erythematosus (Rice et al., 2009). Collectively, SAMHD1 is considered to be a regulator of cellular intrinsic antiviral response (Rice et al., 2009). SAMHD1 has a sterile alpha motif (SAM) and an HD domain in tandem. SAMs are 65-70 residues in length and can serve as protein-interaction modules. The HD domain, which is characterized by a motif with a doublet of divalent-cationcoordinating histidine and aspartic acid residues, is found in a diverse superfamily of enzymes with a potential phosphohydrolase activity. In the article of Laguette et al. (2011) apart from the identification of a novel antiviral cellular factor, authors were mainly concerned about the restriction of Vpx-less HIV-1 replication in myeloid cells but not the replication of the other viruses with Vpx.

From the results of Laguette et al. (2011) future directions in a short or medium range for biological and biochemical characterization of the interaction between HIV/SIV Vpx and SAMHD1 are quite evident and manifold. Most importantly, we should perform a systemic genetic analysis of non-HIV-1 viruses carrying the $v p x$ gene in the presence of SAMHD1. Numerous studies on HIV/SIV Vpx thus far conducted, both in vitro and in vivo, have indicated that Vpx is critical for viruses containing the vpx gene (Fujita et al., 2010). In particular, monkey model studies have clearly demonstrated that $\mathrm{Vpx}$ is quite necessary for viral replication and pathogenesis in individuals. Whether SAMHD1 is a natural target of HIV/SIV Vpx and is a negative modulator of the viruses should be extensively and repeatedly verified. On the other hand, we empirically know that $v p x$-minus HIV- 1 can replicate, spread, and persist, and survive in human populations. If SAMHD1 can determine or alter the outcome of HIV-1 infection in humans, how does HIV-1 overcome its serious negative effect? Can the activity of Vpx be replaced, at least in part, with structurally related HIV-1 Vpr? Alternatively, SAMHD1-mediated virus restriction does not have much impact on the survival of HIV-1 in humans. It is conceivable that

Table 1 | Restriction factors against HIV/SIV.

\begin{tabular}{|c|c|c|}
\hline $\begin{array}{l}\text { Cellular restriction } \\
\text { factors }\end{array}$ & Antiviral activity & $\begin{array}{l}\text { Counteracting or } \\
\text { interacting viral proteins }\end{array}$ \\
\hline${ }^{*} \mathrm{APOBEC3G/F}$ & $\begin{array}{l}\text { Induction of lethal mutations in } \\
\text { viral genome }\end{array}$ & Vif \\
\hline $\begin{array}{l}\text { CypA, *TRIM5 } \alpha, \\
\text { and TRIMCyp }\end{array}$ & Induction of disordered uncoating? & Gag-CA \\
\hline *Tetherin & Inhibition of virion release & Vpu \\
\hline *SAMHD1 & Inhibition of reverse transcription & Vpx \\
\hline
\end{tabular}

* Major restriction factors against HIVISIV so far reported. 
the Vpx-mediated enhancement of viral replication by counteracting SAMHD1 is important for the survival of primate immunodeficiency viruses in monkey species. After all, it is time now to re-start the Vpx study, focusing on SAMHD1 molecule.

\section{REFERENCES}

Bergamaschi, A., Ayinde, D., David, A., Le Rouzic, E., Morel, M., Collin, G., Descamps, D., Damond, F., Brun-Vezinet, F., Nisole, S., Margottin-Goguet, F., Pancino, G., and Transy, C. (2009). The human immunodeficiency virus type $2 \mathrm{Vpx}$ protein usurps the CUL4A-DDB1 DCAF1 ubiquitin ligase to overcome a postentry block in macrophage infection. $J$. Virol. 83, 4854-4860.

Fujita, M., Otsuka, M., Miyoshi, M., Khamsri, B., Nomaguchi, M., and Adachi, A. (2008). Vpx is critical for reverse transcription of the human immunodeficiency virus type 2 genome in macrophages. $J$. Virol. 82, 7752-7756.

Fujita, M., Otsuka, M., Nomaguchi, M., and Adachi, A. (2010). Multifaceted activity of HIV Vpr/Vpx proteins: the current view of their virological functions. Rev. Med. Virol. 20, 68-76.

Goujon, C., Arfi, V., Pertel, T., Luban, J., Lienard, J., Rigal, D., Darlix, J.L., and Cimarelli, A. (2008). Characterization of simian immunodeficiency virus SIVSM/human immunodeficiency virus type $2 \mathrm{Vpx}$ function in human myeloid cells. J. Virol. 82, 12335-12345.

Goujon, C., Riviere, L., Jarroson-Wuilleme, L., Bernaud, J., Rigal, D., Darlix, J. L., and Cimarelli, A. (2007). SIVSM/HIV-2 Vpx proteins promote retroviral escape from a proteasome-dependent restriction pathway present in human dendritic cells. Retrovirology 4, 2.

Gramberg, T., Sunseri, N., and Landau, N. R. (2010). Evidence for an activation domain at the amino terminus of simian immunodeficiency virus Vpx. J. Virol. 84, 1387-1396.

Hartman, Z. C., Kiang, A., Everett, R. S., Serra, D., Yang, X. Y., Clay, T. M., and Amalfitano, A. (2007). Adenovirus infection triggers a rapid, MyD88-regulated transcriptome response critical to acute-phase and adaptive immune responses in vivo. J. Virol. 81, 1796-1812.

Kaushik, R., Zhu, X., Stranska, R., Wu, Y., and Stevenson, M. (2009). A cellular restriction dictates the permissivity of nondividing monocytes/macrophages to lentivirus and gammaretrovirus infection. Cell Host Microbe 6, 68-80.

Khamsri, B., Murao, F., Yoshida, A., Sakurai, A., Uchiyama, T., Shirai, H., Matsuo, Y., Fujita, M., and Adachi, A. (2006). Comparative study on the structure and cytopathogenic activity of HIV Vpr/Vpx proteins. Microbes Infect. 8, 10-15.

Laguette, N., Sobhian, B., Casartelli, N., Ringeard, M., Chable-Bessia, C., Segeral, E., Yatim, A., Emiliani, S., Schwartz, O., and Benkirane, M. (2011). SAMHD1 is the dendritic- and myeloid-cell-specific HIV-1 restriction factor counteracted by Vpx. Nature. doi: 10.1038/nature10117

Li, N., Zhang, W., and Cao, X. (2000). Identification of human homologue of mouse IFN-gamma induced protein from human dendritic cells. Immunol. Lett. $74,221-224$.

Malim, M.H., and Emerman, M. (2008).HIV-1 accessory proteins-ensuring viral survival in a hostile environment. Cell Host Microbe 3, 388-398.

Prehaud, C., Megret, F., Lafage, M., and Lafon, M. (2005). Virus infection switches TLR-3-positive human neurons to become strong producers of beta interferon. J. Virol. 79, 12893-12904.

Rice, G. I., Bond, J., Asipu, A., Brunette, R. L., Manfield, I. W., Carr, I. M., Fuller, J. C., Jackson, R. M., Lamb, T., Briggs, T. A., Ali, M., Gornall, H., Couthard, L. R., Aeby, A., Attard-Montalto, S. P., Bertini, E., Bodemer, C., Brockmann, K., Brueton, L. A., Corry, P. C., Desguerre, I., Fazzi, E., Cazorla, A. G., Gener,
B., Hamel, B. C. J., Heiberg, A., Hunter, M., van der Knaap, M. S., Kumar, R., Lagae, L., Landrieu, P. G., Lourenco, C. M., Marom, D., McDermott, M F., van der Merwe, W., Orcesi, S., Prendiville, J. S. Rasmussen, M., Shalev, S. A., Soler, D. M., Shinawi, M., Spiegel, R., Tan, T. Y., Vanderver, A., Wakeling, E. L., Wassmer, E., Whittaker, E., Lebon, P., Stetson, D. B., Bonthron, D. T., and Crow, Y. J. (2009). Mutations involved in Aicardi-Goutieres syndrome implicate SAMHD1 as a regulator of the innate immune response. Nat. Genet. 41, 829-832.

Sharova, N., Wy, Y., Zhu, X., Stranska, R., Kaushik, R., Sharkey, M., and Stevenson, M. (2008). Primate lentiviral Vpx commanders DDB1 to counteract a macrophage restriction. PLoS Pathog. 4, e1000057. doi: 10.1371/journal.ppat.1000057

Srivastava, S., Swanson, S. K., Manel, N., Florens, L., Washburn, M. P., and Skowronski, J. (2008). Lentiviral Vpxaccessory factor targets VprBP/DCAF1 substrate adaptor forcullin $4 \mathrm{E} 3$ ubiquitin ligase to enable macrophage infection. PLoS Pathog. 4, e1000059. doi: 10.1371/journal.ppat.1000059

Zhao, D., Peng, D., Li, L., Zhang, Q., and Zhang, C. (2008). Inhibition of G1P3 expression found in the different display study on respiratory syncytial virus infection. Virol. J. 5, 114.

Received: 28 May 2011; accepted: 01 June 2011; published online: 10 June 2011.

Citation: Nomaguchi M, Fujita M and Adachi A (2011) The fourth major restriction factor against HIV/SIV. Front. Microbio. 2:132. doi: 10.3389/fmicb.2011.00132

This article was submitted to Frontiers in Virology, a specialty of Frontiers in Microbiology.

Copyright () 2011 Nomaguchi, Fujita and Adachi. This is an open-access article subject to a non-exclusive license between the authors and Frontiers Media SA, which permits use, distribution and reproduction in other forums, provided the original authors and source are credited and other Frontiers conditions are complied with. 